\title{
Seminal plasma clusterin as a biomarker for spermatogenesis in patients with varicocele before and after varicocelectomy
}

\author{
Original \\ Hanan M.A. Saleh ${ }^{1}$, Ahmed Abdelfattah Afify', Walid Abdelhady Ahmed ${ }^{2}$, \\ Article \\ Maged S. Daruish ${ }^{1}$ \\ ${ }^{1}$ Departments of Dermatology, Venereology and Andrology, ${ }^{2}$ Clinical Pathology, Faculty of \\ Medicine, Ain Shams University, Cairo, Egypt
}

\begin{abstract}
Introduction: A varicoc ele is an abnormally dilated pampiniform plexus of veins. Hyperthermia, oxidative stress, and elevated apoptotic index have been described in men with varicocele and infertility. Clusterin (Clu) is a chaperone-like glycoprotein that is synthesized by Sertoli cells in high concentrations and is deposited onto the membranes of mature spermatozoa, giving rise to the possibility that it has a role in sperm development. Secreted form of Clu is a powerful antiapoptotic agent.

Aim: To explore Clu level in seminal plasma of infertile men with varicocele in comparison with normal healthy fertile patients and to compare the seminal plasma Clu level before and after varicocelectomy.

Patients and methods: The study included 25 patients having varicocele with infertility (whether primary or secondary) for 12 months and 10 healthy volunteers of matched age and sex as control. For all the patients, sub-inguinal varicocelectomy was done. Semen analysis and seminal plasma Clu assay were carried out before and 3 months after varicocelectomy.

Results: There was a statistically significant difference between patients and controls regarding sperm count, progressive motility, and seminal plasma Clu $(P<0.01)$. Three months after varicocelectomy, the sperm count had a highly significant improvement in the patient's group (mean $\pm \mathrm{SD}=17.90 \pm 8.86)$ compared with a preoperative count (mean $\pm \mathrm{SD}=11.43$ \pm 7.56). There was a highly significant improvement in postoperative progressive motility in the patient's group (mean \pm $\mathrm{SD}=34.5 \pm 20.2$ ) compared with a preoperative progressive motility (mean $\pm \mathrm{SD}=22.05 \pm 15.5$ ).

Clu showed a highly significant elevation in the patient group postoperatively (mean $\pm \mathrm{SD}=10.73 \pm 4.5$ ) compared with preoperatively (mean $\pm \mathrm{SD}=6.68 \pm 3.8$ ).

Conclusion: Based on our study, we could suggest another way of contribution of varicocele to male infertility by affecting seminal plasma Clu level.
\end{abstract}

Key Words: Patients with varicocele, seminal plasma clusterin, spermatogenesis, varicocelectomy

Received: 9 January 2019, Accepted: 28 February 2019

Corresponding Author: Maged S. Daruish, Resident, Department of Andrology, Faculty of Medicine, Ain Shams University, Cairo, Egypt, 11517, Tel.: +201062620966, E-mail: mageddaruish@gmail.com

ISSN: 2090-6048, December 2018 Vol.8, No.4

\section{INTRODUCTION}

Clusterin $(\mathrm{Clu})$ is a soluble glycoprotein that is found in high concentrations in body fluids. Clu consists of two chains; $\alpha$-Clu and $\beta-\mathrm{Clu}^{[1]}$.

Clu has chaperone-like activity ${ }^{[2]}$, by binding to misfolded proteins through the hydrophobic zones present in its structure and preventing those proteins from accumulating $^{[3]}$.

Several functions have been attributed to Clu such as complement regulation, lipid transport, apoptosis, and cell differentiation. It was found to be involved in the pathogenesis of many disorders such as Alzheimer's disease, cancers, and autoimmune disorders ${ }^{[1]}$.

In the male genital tract, $\mathrm{Clu}$ is the main protein synthesized by Sertoli cells and is deposited onto the membranes of elongating spermatids and mature spermatozoa, giving rise to the possibility that it has a role in sperm development ${ }^{[4]}$.

Two main forms of Clu protein exist: secretory Clu, which is anti-apoptotic, and nuclear Clu, which is proapoptotic ${ }^{[5]}$. Secretory $\mathrm{Clu}$ is a powerful anti-apoptotic agent, as it inhibits pro-apoptotic signals and suppresses p53 and Bax pathways ${ }^{[6]}$.

Regarding the role of $\mathrm{Clu}$ in fertility, it has been suggested that Clu may have a role in sperm maturation ${ }^{[7]}$ and that inhibiting Clu gene expression leads to elevation of the apoptotic index, under heat exposure ${ }^{[8]}$.

A varicocele is an abnormally dilated pampiniform plexus of veins ${ }^{[9]}$. Its prevalence is $35-50 \%$ among men with primary infertility and $80 \%$ among men with secondary infertility ${ }^{[10]}$. 
Many theories have been postulated to explain the mechanism through which varicocele can affect fertility, for example, elevated temperature, alterations of hypothalamic-pituitary-gonadal axis, oxidative stress, and increased apoptosis ${ }^{[10]}$. These findings suggest that varicocele through the theory of hyperthermia might lead to inhibition of Clu gene expression leading to elevation of the apoptotic index.

Serum and seminal Clu levels have been described as a predictor of sperm retrieval in MD-TESE in nonobstructive azoospermic patients, and it has been suggested that evaluation of the seminal Clu level could be used as a biomarker for the spermatogenesis in infertile men ${ }^{[11]}$.

\section{AIM OF THE WORK}

The aim is to explore Clu level in seminal plasma of infertile men with varicocele in comparison with normal healthy fertile patients and to compare the seminal plasma Clu level before and after varicocelectomy

\section{PATIENTS AND METHODS}

Our study included 25 patients having varicocele with infertility (whether primary or secondary) for 12 months. The study also included 10 healthy volunteers of matched age and sex as control. Our participants were recruited from the Andrology Outpatient Clinic of Ain Shams University hospitals after obtaining approval of the institutional review board and patient consents.

All grades of varicocele were included; grading was applied according to scrotal duplex results. Azoospermic or severe oligozoospermic patients were excluded.

For all the patients, sub-inguinal varicocelectomy was done. Semen analysis, scrotal duplex, and seminal Clu assay were carried out before and 3 months after varicocelectomy.

Semen analyses were carried out for each patient according to $\mathrm{WHO}$ criteria $^{[12]}$.

\section{Technique of clusterin assessment}

Clusterin assessment was done as follows:

1. Semen samples were stored at $-80^{\circ} \mathrm{C}$ for subsequent evaluation $^{[11]}$.

2. Semen was analyzed for Clu using sandwich enzyme-linked immunosorbent assay (ELISA) by the human Clu ELISA kit (Shanghai Korean Biotech Co. Ltd, Shanghai, China).

3. Clu assessment was done for all the participants of the study on at least two semen samples for each participant and blinded assessment has been repeated twice for each sample.

\section{Statistical analysis}

The collected data were revised, coded, tabulated, and introduced to a PC using statistical package for the social science (2001, SPSS 15.0.1 for Windows; SPSS Inc., Chicago, Illinois, USA). $P$-value less than 0.05 was considered statistically significant.

\section{RESULTS}

The preoperative sperm count in the patient group ranged from 5 to 36 million $/ \mathrm{ml}($ mean $\pm \mathrm{SD}=11.43 \pm 7.56)$ compared with 31-155.2 million $/ \mathrm{ml}$ (mean $\pm \mathrm{SD}=80.9 \pm$ 35.3 ) in the control group. The preoperative progressive motility $(\mathrm{a}+\mathrm{b})$ in the patient group ranged from 5 to $55 \%$ (mean $\pm \mathrm{SD}=22.05 \pm 15.5$ ) compared with $35-65 \%$ (mean $\pm \mathrm{SD}=48.5 \pm 11.3$ ) in the control group. There was a statistically significant difference between patients and controls regarding sperm count and sperm progressive motility $(P<0.01)$ (Table 1$)$.

Table 1: Comparison between patients and controls regarding preoperative semen parameters and preoperative seminal plasma clusterin

\begin{tabular}{|c|c|c|c|c|}
\hline Before & $\begin{array}{c}\text { Control } \\
\text { group }(\mathrm{N}=10)\end{array}$ & $\begin{array}{c}\text { Patients } \\
\text { group }(\mathrm{N}=22)\end{array}$ & P-value & Significance \\
\hline \multicolumn{5}{|l|}{ Volume } \\
\hline Mean \pm SD & $3.79 \pm 1.64$ & $3.25 \pm 1.32$ & 0.327 & NS \\
\hline Range & $1.5-7$ & $1.5-6.5$ & & \\
\hline \multicolumn{5}{|c|}{ Total sperm count (ml) } \\
\hline Mean \pm SD & $80.9 \pm 35.3$ & $11.43 \pm 7.65$ & 0.000 & HS \\
\hline Range & $31-155.2$ & $5-36.4$ & & \\
\hline \multicolumn{5}{|c|}{ Sperm count/ejaculate } \\
\hline Mean \pm SD & $290.6 \pm 145.19$ & $35.5 \pm 26.7$ & 0.000 & HS \\
\hline Range & $108-525$ & $7.7-140$ & & \\
\hline \multicolumn{5}{|c|}{ Progressive motility } \\
\hline Mean \pm SD & $48.50 \pm 11.3$ & $22.05 \pm 15.5$ & 0.001 & HS \\
\hline Range & $12.5-65$ & $5-55$ & & \\
\hline \multicolumn{5}{|c|}{ Non progressive motility } \\
\hline Mean \pm SD & $21.50 \pm 6.25$ & $27.50 \pm 13.87$ & 0.228 & NS \\
\hline Range & $10-30$ & $5-60$ & & \\
\hline \multicolumn{5}{|c|}{ Immotile sperms } \\
\hline Mean \pm SD & $30 \pm 14.14$ & $50.6 \pm 19.9$ & 0.013 & $\mathrm{~S}$ \\
\hline Range & $15-69.1$ & $20-90$ & & \\
\hline \multicolumn{5}{|c|}{ Abnormal forms } \\
\hline Mean \pm SD & $22.9 \pm 5.84$ & $26.7 \pm 9.4$ & 0.244 & NS \\
\hline Range & $8-28$ & $15-60$ & & \\
\hline \multicolumn{5}{|c|}{ Seminal plasma clusterin } \\
\hline Mean \pm SD & $35.4 \pm 36.6$ & $6.68 \pm 3.8$ & 0.000 & HS \\
\hline Range & $10-130$ & $1-20$ & & \\
\hline
\end{tabular}

HS, highly significant; S, significant. 
The preoperative Clu level in the patient's group ranged from 1 to $20 \mathrm{ng} / \mathrm{ml}$ (mean $\pm \mathrm{SD}=6.68 \pm 3.8$ ), whereas the $\mathrm{Clu}$ in the control group ranged from 10 to 130 $\mathrm{ng} / \mathrm{ml}$ (mean $\pm \mathrm{SD}=35.4 \pm 36.6$ ). There was a statistically highly significant difference between patients and controls regarding seminal plasma Clu level $(P<0.01)$ (Table 1).

Three months after varicocelectomy, there was a highly significant improvement in the sperm count and progressive motility $(P<0.01)$. The postoperative sperm count had a highly significant improvement in the patient group (17.90 \pm 8.86$)$ compared with a preoperative count $(11.43 \pm 7.56)(P<0.01)$, and the postoperative progressive motility showed a highly significant improvement in the patient group $(34.5 \pm 20.2)$ compared with a preoperative progressive motility $(22.05 \pm 15.5)(P<0.01)$ (Table 2$)$.

Table 2: Comparison between semen Parameters and seminal plasma clusterin of patient group before and after operation

\begin{tabular}{|c|c|c|c|c|}
\hline & $\begin{array}{l}\text { Before } \\
(\mathrm{N}=22)\end{array}$ & After $(\mathrm{N}=22)$ & $P$-value & Significance \\
\hline \multicolumn{5}{|c|}{ Total sperm count $(\mathrm{ml})$} \\
\hline Mean \pm SD & $11.43 \pm 7.56$ & $17.90 \pm 8.86$ & 0.001 & HS \\
\hline Range & $5-36.4$ & $0.6-38.4$ & & \\
\hline \multicolumn{5}{|c|}{ Sperm count/ejaculate } \\
\hline Mean \pm SD & $35.57 \pm 26.7$ & $60.6 \pm 41.1$ & 0.001 & HS \\
\hline Range & $7.7-140$ & $1.5-140.5$ & & \\
\hline \multicolumn{5}{|c|}{ Progressive motility } \\
\hline Mean \pm SD & $22.05 \pm 15.5$ & $34.5 \pm 20.2$ & 0.03 & HS \\
\hline Range & $5-55$ & $0-65$ & & \\
\hline \multicolumn{5}{|c|}{ Non progressive motility } \\
\hline Mean \pm SD & $27.50 \pm 13.87$ & $25.68 \pm 11.88$ & 0.228 & NS \\
\hline Range & $5-60$ & $10-55$ & & \\
\hline \multicolumn{5}{|c|}{ Immotile sperms } \\
\hline Mean \pm SD & $50.68 \pm 19.9$ & $40.0 \pm 21.6$ & 0.01 & $\mathrm{~S}$ \\
\hline Range & $20-90$ & $15-80$ & & \\
\hline \multicolumn{5}{|c|}{ Abnormal forms } \\
\hline Mean \pm SD & $26.77 \pm 9.47$ & $26.95 \pm 6.55$ & 0.943 & NS \\
\hline Range & $15-60$ & $15-40$ & & \\
\hline \multicolumn{5}{|c|}{ Seminal plasma clusterin } \\
\hline Mean \pm SD & $6.68 \pm 3.8$ & $10.73 \pm 4.57$ & 0.000 & HS \\
\hline Range & $1-20$ & $5-22$ & & \\
\hline
\end{tabular}

HS, highly significant; S, significant.

Postoperative Clu level showed a highly significant elevation in the patient group $(10.73 \pm 4.5)$ compared with preoperative Clu level $(6.68 \pm 3.8)(P<0.01)$ (Table 2).

\section{DISCUSSION}

Clu is the main protein synthesized by Sertoli cells ${ }^{[4]}$. It seems to play an important role in sperm maturation ${ }^{[7]}$ and acts as an integral anti-apoptotic protein ${ }^{[8]}$. Elevated apoptotic index is one of the main findings in men with varicocele and infertility ${ }^{[10]}$.

Our study showed statistically significant difference in seminal Clu level between infertile patients with varicocele and controls. This agrees with previous findings that $\mathrm{Clu}$ and other heat shock proteins are lower in amount in men with varicocele ${ }^{[13]}$.

The lower levels of seminal $\mathrm{Clu}$ in men with infertility and varicocele may be explained by multiple factors: oxidative stress interfering with processing, level, and function of the mature $\mathrm{Clu}$ form ${ }^{[14]}$ and the negative correlation between seminal Clu level and DNA fragmentation $^{[15]}$.

This is the first study to measure Clu level by ELISA before and after varicocele surgery in infertile patients. We found a significant elevation in seminal Clu level after varicocelectomy.

This elevation may be explained by improvement in the microenvironment, less stressed sperms, lower levels of stressed proteins, and although not measured, an improvement in oxidative stress and DNA fragmentation.

\section{CONCLUSION}

Clu may play an important role in infertility in men with varicocele and correction of varicocele improves the seminal Clu level.

\section{CONFLICTS OF INTEREST}

There are no Confilict of Interest

\section{REFERENCES}

1. Matukumalli SR, Tangirala R, Rao CM. Clusterin: full-length protein and one of its chains show opposing effects on cellular lipid accumulation. Sci Rep 2017; 7:1-13.

2. Cunin $\mathrm{P}$, Beauvillain $\mathrm{C}$, Miot $\mathrm{C}$, Augusto JF, Preisser L, Blanchard $\mathrm{S}$ et al. Clusterin facilitates apoptotic cell clearance and prevents apoptotic cell-induced autoimmune responses. Cell Death Dis 2016; 7:e2215.

3. Bailey RW, Dunker AK, Brown CJ, Garner EC, Griswold MD et al. Clusterin, a binding protein with a molten globule-like region. Biochemistry 2001; 40:11828-11840.

4. Tenniswood M, Wang Z, Lakins J, Morrissey C, O'Sullivan J, Tang $\mathrm{H}$ et al. Clusterin in the male reproductive tract. J Androl 1998; 19:508-516. 
5. Xiu P, Dong XF, Li XP, Li J. Clusterin: review of research progress and looking ahead to direction in hepatocellular carcinoma. World J Gastroenterol 2015; 21:8262-8270.

6. Wilson MR, Zoubeidi A. Clusterin as a therapeutic target. Expert Opin Ther Targets $2017 ; 21: 201-213$.

7. Sylvester SR, Morales C, Oko R, Griswold MD. Localization of sulfated glycoprotein-2 (clusterin) on spermatozoa and in the reproductive tract of the male rat. Biol Reprod 1991; 45:195-207.

8. Matsushita K, Miyake H, Chiba K, Fujisawa $\mathrm{M}$ et al. Clusterin produced by Sertoli cells inhibits heat stress-induced apoptosis in the rat testis. Andrologia 2016; 48:11-19.

9. Chan C, Sun G, Shui H, Wu G. Basic and translational science differential spermatozoal protein expression pro files in men with varicocele compared to control subjects: upregulation of heat shock. Urology 2013; 81:1379-1381.

10. Agarwal A, Sharma R, Durairajanayagam D, et al. Differential proteomic profiling of spermatozoal proteins of infertile men with unilateral or bilateral varicocele. Urology 2015; 85:580-588.
11. Fukuda T, Miyake H, Enatsu N, Matsushita K, M. Fujisawa et al. Seminal level of clusterin in infertile men as a significant biomarker reflecting spermatogenesis. Andrologia 2016; 48:1188-1194.

12. World Health Organization. WHO laboratory manual for the examination and processing of human semen. 5th ed. Geneva: World Health Organization; 2010. 271.

13. Hosseinifar H, Gourabi H, Salekdeh GH, Alikhani M, Mirshahvaladi S, Sabbaghian $M$, et al Study of sperm protein profile in men with and without varicocele using two-dimensional gel electrophoresis. Urology 2013; 81:293-300.

14. Sharma R, Agarwal A, Mohanty G, Du Plessis SS, Gopalan B, Willard B, et al. Proteomic analysis of seminal fluid from men exhibiting oxidative stress. Reprod Biol Endocrinol 2013; 11:85.

15. Salehi M, Akbari H, Heidari MH, Molouki A, Murulitharan K, Moeini $\mathrm{H}$ et al. Correlation between human clusterin in seminal plasma with sperm protamine deficiency and DNA fragmentation. Mol Reprod Dev 2013; 80:718-724. 